\title{
PELATIHAN TENTANG MODEL-MODEL PEMBELAJARAN BAHASA INDONESIA DI SD PADA GURU-GURU SD DI KECAMATAN TOMOHON TENGAH
}

\author{
Neltje Kambey \\ Prodi PGSD, Fakultas Ilmu Pendidikan, Universitas Negeri Manado
}

\begin{abstract}
Abstrak
One of the powerful thing of Indonesia in developing this countryis Indonesian language. It is a tool of communication formally used for all the society and to all institution in Indonesia. The instruction of Indonesia language implemented in all level of education in Indonesia started from Elementary till the higher education. The primary school teacher should create an interesting condition in language instruction to make students enjoyable in learning in order to improve both of their love as well as their ability in Indonesia language. To reach this purposes, the teachers need to know, to master, to have skill in determine the appropriate models of teaching in Indonesia languange, and also have ability to apply them in instruction. The teacher really need to be trained the inovative models of teaching so that they can understand about it. They also need to work together with their collegous to help each other in arranging the lesson plan and to simulate among them. This activity gives them opportunity to repair their conventionl instruction to the new one for the better students as well as the better Indonesian in the future.

Kata Kunci: Model-model pembelajaran, Pembelajaran inovatif, Guru Sekolah Dasar.
\end{abstract}

\section{PENDAHULUAN}

Pendidikan merupakan salah satu faktor penting yang perlu diperhatikan dalam rangka mengisi program pembangunan, karena hanya melalui pendidikan dapat dibentuk manusia yang berkualitas sesuai dengan tuntutan kemajuan dan kebutuhan pembangunan. Sekolah sebagai lembaga pendidikan merupakan salah satu faktor penting yang turut menentukan terwujudnya tujuan pendidikan. Agar sekolah dapat menjalankan misinya maka perlu kerjasama yang harmonis antara setiap komponen yang terkait di dalamnya. Peranan Guru sangat menentukan dalam pencapaian tujuan pendidikan. Usaha-usaha untuk meningkatkan mutu pendidikan sangat bergantung pada pihak guru. Berbagai masalah sering muncul dalam kegiatan belajar mengajar di sekolah, seperti rendahnya hasil belajar siswa. Masalah ini harus diatasi karena masalah tersebut adalah tanggung jawab guru dan pihak-pihak yang terlibat dalam proes belajar mengajar. Karena guru mempunyai pengaruh dominan terhadap kualitas pengajaran maka dalam pribadi guru dalam mengatasi masalah tersebut dituntut kemampuan intelektual dan kemampuan profesional.

Peranan guru dalam kegiatan pembelajaran sangat penting, sebab itu penguasaan terhadap model-model pembelajaran bahasa harus diketahui oleh setiap guru pada setiap jenjang pendidikan. Namun kenyataan yang ada masih banyak guru yang belum mampu melaksanakan kegiatan pembelajaran dengan baik dan 
optimal. Dimana, menurut Djamarah S.B. dan Zaiti Aswan (2010), bahwa paling sedikit ada tiga aspek yang membedakan anak didik yang satu dengan yang lainnya, yaitu aspek intelektual, psikologis, dan biologis.

Ketiga aspek tersebut merupakan akar permasalahan yang menyebabkan bervariasinya sikap dan tingkah laku anak didik. Hal ini menjadi tugas yang cukup berat bagi pengajar dalam mengelola kelas dengan baik. Karena kegagalan dalam menngelola kelas mengakibatkan tujuan pengajaranpun sukar dicapai. Untuk itu, pengajar perlu melakukan berbagai pembelajaran antara lain, dengan menerapkan model-model pembelajaran bahasa yang tepat dalam pembelajaran. Karena modelmodel pembelajaran bahasa mempunyai andil yang cukup besar dalam kegiatan belajar mengajar. Dimana kemampuan yang diharapkan dapat dimiliki oleh anak didik dalam hal ini prestasi belajar yag baik, akan ditentukan oleh kerelevasian penggunaan suatu model pembelajaran dengan tujuan. Ini berarti bahwa tujuan pembelajaran akan dapat dicapai dengan penggunaan model yang tepat, sesuai dengan standar keberhasilan yang telah ditentukan dalam tujuan pembelajaran.

Pembelajaran bahasa di sekolah dasar, umumnya mengalami kesulitan, hal ini disebabkan karena pembelajaran bahasa sejak awal sudah dianggap sulit oleh siswa. Akibatnya para siswa akan menemui kesulitan untuk memahami 98 konsep-konsep bahasa tersebut, terlebih lagi bila metode yang digunakan dalam penyampaian materi tidak sesuai dengan karakteristik materi dan siswa maka akan lebih menyulitkan siswa utuk menerimanya. Karena itu, guru disamping harus memiliki pengetahuan dan kemampuan serta pemahaman yang baik mengenai konsepkonsep bahasa, juga memiliki kemampuan dalam melakukan inovasi dalam pembelajaran, dalam hal ini, dengan menerapkan metode pembelajaran yang tepat dan sesuai dengan karakteristik materi dan karakteristik siswa, kemampuan mengelola kelas, serta strategi belajar mengajar. Tentu saja hal ini perlu perancangan materi, dengan kata lain bila akan menerapkan suatu pendekatan dalam pembelajaran bahasa maka perlu disusun strategi belajar mengajarnya. Hal ini sejalan dengan yang dikemukakan oleh Ruseffendi (1990). bahwa strategi belajar mengajar terpilih, kita tentukan metode mengajarnya, untuk bidang studi/topik tertentu, teknik mengajar, dan akhirnya kita pilih alat peraga atau media pengajaran pada umumnya.

Belajar mengajar sebagai suatu sistem instruksional mengacu kepada pengertian sebagai seperangkat komponen yang saling bergantung satu sama lain untuk mencapai tujuan, Agar tujuan itu tercapai maka semua komponen harus diorganisasikan secara strategis dan sistemik. Karena itu, guru tidak boleh hanya memperhatikan komponen-komponen pe- 
ngajaran secara parsial, misalnya metode terpisah dari bahan, bahan tidak mendukung istem evaluasi dan seterusnya. Oleh karena itu, dalam kegiatan mengajar biasanya guru dihadapkan pada beberapa persoalan pokok, seperti: (1) tujuan apa yang akan dicapai; (2) materi apa yang perin diberikan; (3) metode dan alat mana yang akan dipakai; (4) kondisi bagaimana yang dapat membelajarkan siswa; dan 5) prosedur apa yang akan ditempuh dalam evaluasi.

Sehubungan dengan tujuan utama kegiatan mengajar adalah membelajarkan siswa, maka teramat bijak apabila guru mampu mengenali, memahami dan menerima karakter siswa yang berkaitan dengan: (1) tingkat kecerdasan dan bakat anak; (2) prestasi awal; (3) perkembangan jasmani dan kesehatan; (4) cita-cita, sikap, minat dan hobi; (5) kebiasaan dan latar sosial keluarga; dan (6) sifat-sifat khusus dan persoalan pribadi anak. Dengan pengetahuan tersebut, inovasi pebelajaran yang dilakukan akan memperoleh hasil yang baik. Kegiatan pengabdian pada masyarakat di bidang pendidikan khususnya dalam rangka pengembangan ilmu pengetahuan dan teknologi masih jarang dilaksanakan.

Berdasarkan hasil observasi dan wawancara yang dilakukan di sekolah tersebut, bahwa disekolah tersebut memiliki beberapa permasalahan dalam pelaksanaan pembelajaran di sekolah, dalam hal ini, prestasi belajar siswa pada mata pelajaran bahasa umumnya relatif rendah.

Sebagai mitra dalam pelaksanaan kegiatan pengabdian masyarakat ini adalah Sekolah Dasar Kecamatan Sario Manado Tengah. Berdasarkan analisis situasi dapat teridentifikasi beberapa permasalahan yang dihadapai oleh mitra, yaitu:

1. Rendahnya prestasi belajar siswa khususnya untuk bidang ilmu tertentu, seperti bahasa. Hal ini disebabkan karena metode yang digunakan dalam pembelajaran di kelas kurang lebih sama yaitu dengan menggunakan metode ceramah;

2. Guru belum bisa menaikkan level pembelajaran dalam kelas agar siswa terstimulus dalam belajar;

3. Penggunaan model pembelajaran kurang sesuai dengan karateristik siswa dan materi yang diberikan; dan

4. Guru kurang memiliki pengetahuan dan keterampilan dalam mengembangkan model pembelajaran yang kreatif.

Dalam identifikasi permasalahan yang ada, maka yang menjadi prioritas dalam hal ini adalah guru, dimana guru merupakan aktor utama dan menjadi sentral dalam kelas. Guru akan berperan secara penuh dan secara aktif yang akan menghidupkan kelas. Kemampuan guru dalam memberikan transfer ilmu kepada para siswa akan sangat tergantung dari cara mengajarnya dalam kelas, serta bagaimana penggunaan model pembelajaran. Keaktifan dan hasil belajar siswa akan sangat 
bergantung dari cara guru dalam mengajar, menyampaikan pelajaran. Metode ceramah dan penggunaan media pembelajaran yang selama ini digunakan, mungkin dianggap menjadi suatu hal yang biasa karena siswa telah mengikuti metode ceramah selama bertahun-tahun dengan menggunakan buku teks dan papan tulis sebagai media dalam, mengikuti pelajaran di sekolah. Dengan kemampuan guru menerapkan metode pembelajaran yang kreatif seperti antara lain Enguiry Leaming maka diharapkan bisa membawa suatu pengalaman pembelajaran yang baru dan diharapkan bisa lebih menstimulus dalam belajar. Peran serta pihak pemerintah sangat penting bagi sekolah dalam hal pengadaan fasilitas penunjang dalam proses pembelajaran di sekolah.

$$
\text { Target pelaksanaan pelatihan }
$$

model- model pembelajaran bagi guru guru bahasa Sekolah Dasar di Kecamatan Sario Manado Tengah yaitu:

1. Penerapan dalam pelaksanaan dan pengembangan model-model pembelajaran bahasa dalam proses pembelajaran;

2. Dapat meningkatkan kemampuan sumber daya manusia dari guru-guru sekolah dasar yang ada, diharapkan akan membuat kelas lebih interaktif lagi, dan siswa lebih terstimulus lagi mengikuti pembelajaran di kelas; dan

3. Penerapan proses pembelajaran yang kreatif dan menarik

Untuk mengatasi permasalahan yang dihadapi dengan sasaran guru-guru Sekolah Dasar di Kecamatan Sario Manado 100
Tengah diperoleh berbagai bentuk permasalahan, yaitu:

1. Meningkatkan kemampuan guru-guru sekolah dasar yang mampu mengembangkan dan menerapkan model-model pembelajaran dalam proses pembelajaran; dan

2. Meningkatkan pemahaman guru-guru sekolah dasar dalam menerapkan model-model pembelajaran Enquiry Learning dalam proses pembelajaran di sekolah.

\section{METODE PELAKSANAAN}

Secara garis besar prosedurnya adalah: ceramah, sharing, and Simulation. Guru mulai bertanya dengan mengajukan persoalan atau menyuruh anak didik atau mendengarkan uraian yang memuat permasalahan. Pelaksanaan program ini adalah mengadakan pelatihan atau workshop penerapan model-model pembelajaran bagi guru-guru bahasa di Kecamatan Sario Manado Tengah. Kegiatan ini bertujuan untuk mendorong, memotivasi guru di sekolah agar dapat melakukan kegiatan pembelajaran lebih menarik, kreatif, dan inovatif tidak banyak guru yang memiliki inisiatif untuk bangkan diri secara mandiri. Jadi pelatihan yang terorganisir dipandang perlu untuk agar dapat menstimulasi pengembangan profesionalitas guru, dengan mapan agar guru semakin terbuka sehingga inisitaif pun semakin besar, Penerapan dengan model pembelajaran ini diharapkan dapat menjembatani siswa 
untuk ikut ketertarikan dalam belajar, untuk memudahkan siswa dalam memahami pelajaran diberikan, sehingga tujuan utama pembelajaran dapat tercapai. Untuk melaksanakan kegiatan ini, maka dilaksanakan secara bermitra antara tim yaitu dari dosen-dosen Program Studi Pendidikan Sekolah Dasar Universitas Negeri Manado dengan Kepala Sekolah Dasar di Kecamatan Sario Manado Tengah.

Agar pelaksanaan kegiatan ini lebih terarah, maka prosedur pelaksanaan kegiatan ini dibagi menjadi 4 tahapan yaitu yang digunakan adalah perencanaan, pelaksanaan/tindakan, evaluasi dan refleksi hasil kegiatan, dan yang terakhir pelaporan hasil kegiatan. Adapun uraian dari setiap tahapan kegiatan adalah sebagai berikut;

1. Tahap Perencanaan, dilakukan setelah dilaksanakan survey dan analisa situasi terhadap lokasi kegiatan. Kegiatan yang dilakukan pada tahapan ini adalah tim pelaksana mengundang kepala-kepala sekolah yang akan menjadi mitra untuk membicarakan maksud dan tujuan, serta mekanisme pelaksanaan kegiatan ini. Selain itu juga membicarakan hal-hal teknis yang mengenai pelaksanaan kegiatan. Setelah mengkoordinasikan pelaksanaan kegiatan maka tim pelaksana menyusun program pelatihan atau workshop.Selain itu juga pada tahapan ini dilakukan pengumpulan alat dan bahan yang akan digunakan.

2. Pelaksanaan Pelatihan, merupakan tahapan pelaksanaan pelatihan atau workshop pelaksanaannya dikerjakan sesuai dengan program yang telah dibuat. Pelatihan atau workshop yang dimaksudkan direncanakan akan diadakan dalam 2 bagian, yaitu (!) Pengenalan dari berbagai model pembelajaran yang inovatif untuk pelajaran bahasa: dan (2) Pelaksanaan pelatihan dengan menggunakan model-model pembelajaran. Enquiry Learning. Untuk melaksanakan kegiatan tersebut digunakan beberapa metode pelatihan, yaitu:

a. Metode Ceramah, dipilih untuk memberikan penjelasan tentang Model Pembelajaran Enquiry Learning, dimana langkah-langkah dalam dalam model pembelajaran ini, yaitu: pemberian masalah kepada guru, pengajuan hipotesis (spesifikasi permasalahan), pengumpulan data, pengolahan data untuk menjawab hipotesis yang telah diajukan, dan pembuatan kesimpulan;

b. Metode Tanya Jawab, metode yang sangat penting bagi para peserta pelatihan, baik di saat menerima penjelasan tentang serta saat mempraktekkannya, metode ini memungkinkan guru-guru menggali pengetahuan sebanyak-banyaknya tentang materi yang diberikan dan juga pengalaman setelah praktek;

c. Metode Simulasi, sangat penting diberikan kepada para peserta pelatihan untuk memberikan 
kesempatan mempraktekan materi pelatihan yang diperoleh. Harapannya, peserta pelatihan akan benarbenar menguasai materi pelatihan yang diterima, mengetahui tingkat kemampuannya menerapkan Empiry Learning secara teknis dan kemudian mengidentifikasi kesulitan-kesulitan (jika masih ada) untuk kemudian dipecahkan.

d. Evaluasi dan Refleksi, sehingga dapat diketahui sejauh mana pemahaman peserta terhadap apa yang diberikan. Evaluasi juga dilakukan terhadap tingkat pemahaman peserta secara teori dan praktek. Refleksi dilakukan terhadap sejauh mana tingkat keberhasilan kegiatan yang telah dilaksanakan. Selain itu juga bertujuan untuk mengetahui kekurangan dan kelebihan dari kegiatankegiatan yang telah dilaksanakan dalam rangka untuk menetapkan rekomendasi terhadap keberlangsungan atau pengembangan kegiatan-kegiatan berikutnya. Dengan kata lain ada tindak lanjut program yang sama.

\section{HASIL DAN PEMBAHASAN}

Setelah pelaksanaan kegiatan selesai, maka dibuat pelaporan dari hasil kegiatan yang telah dilaksanakan sebagai bukti pertanggungjawaban terhadap instansi yang menugaskan, bahwa kegiatan telah dilaksanakan.
Sasaran kegiatan ini adalah guruguru bahasa sekolah dasar di Kecamatan Sario Manado Tengah. Pemilihan dan penetapan sasaran pelatihan ini mempunyai pelaksanaan pengembangan rasional strategis dalam kaitannya dengan upaya peningkatan kualitas para guru tersebut tentang pengembangan dan pemanfaatan model - model pembelajaran bahasa di sekolah dasar di Kecamatan Sario Manado Tengah di masa mendatang.

Kegiatan pelatihan ini merupakan bentuk pembinaan kemampuan guru - guru untuk menetapkan model - model pembelajaran bahasa. Dilihat dari profesi dan pengalamannya, guru - guru ini, memiliki potensi pengetahuan dan kemampuan untuk, menggunakan/ menerapkan model - model pembelajaran bahasa. Dilihat dari lingkungannya sekolah memiliki sumber yang memilik media untuk dapat terus untuk meningkatan prestasi guru - guru dalam penerapan metode model - model pembelajaran bahasa.

Pelaksanaan kegiatan ini diawali dengan menyusun beberapa alternatif pemecahan masalah. Ada beberapa alternatif yang dapat dilakukan dalam memecahkan permasalahan yang dihadapi dalam hal memaksimalkan penggunaan model - model pembelajaran bahasa dalam pembelajaran, yaitu:

1. Pimpinan sekolah mewajibkan kepada para guru untuk secara mandiri mengembangkan suatu inovasi, khususnya yang berkaitan dengan upaya 
menciptakan suatu situasi pembelajaran yang interaktif dan menarik yang didalamnya bisa terselenggara kegiatan pembelajaran yang sesuai dengan tujuan dan hakekat dari setiap mata pelajaran yang diajarkan;

2. Pemerintah menyediakan tenaga guru yang menguasai berbagai model-model pembelajaran bahasa di sekolahsekolah; dan

3. Kepada guru diberikan kursus dan pelatihan singkat mengenai penggunaan/penerapan model-model pembelajaran bahasa dalam proses pembelajaran.

Pada dasarnya semua alternatif yang telah dijelaskan dapat ditempuh, tetapi bila dipertimbangkan lebih jauh dari berbagai segi, seperti kesiapan para guru, dana yang dapat di sediakan, motivasi dari para guru itu sendiri dan lain-lain, maka alternatif yang ketiga lebih tepat untuk dipilih dan dilaksanakan, terutama dalam jangka pendek karena yang dikehendaki adalah perubahan yang segera diwujudkan. Bila alternatif pertama yang dipilih, persoalannya adalah apakah para guru memiliki kesiapan untuk segera melakukan inovasi pembelajaran. Apakah wawasan dan motivasi yang kini dimiliki memadai, dan apakah guru memiliki kesiapan untuk itu? Jika alternatif 2 yang dipilih, persoalannya adalah apakah sekolah dan pemerintah dapat segera menyediakan tenaga guru yang diperlukan? Berdasarkan pertimbangan-pertimbangan tersebut maka alternatif yang ketiga lebih tepat untuk dipilih dengan beberapa alasan sebagai berikut:

1. Para guru tidak harus meninggalkan aktivitasnya dalam waktu yang cukup lama;

2. Untuk kebutuhan pelatihan, para guru tidak perlu mengeluarkan biaya pelatihan, malah mendapatkan bantuan seperlunya untuk bahan-bahan yang diperlukan seperti modul, CD pembelajaran, dan lain-iain;

3. Adanya lembaga pendidikan yang sanggup melaksanakan kegiatan ini (Program Studi Pendidikan Guru Sekolah Dasar Universitas Negeri Manado yang memiliki tenaga profesional dalam bidangnya;

4. Para guru sangat tertarik dan berkeinginan untuk mengikuti pelatihan ini. Jadi pemecahan masalahnya adalah dengan melaksanakan pelatihan dan kursus singkat secara langsung di lokasi atau wilayah yang menjadi sasaran kegiatan ini. Kegiatan yang dilakukan oleh suatu tim yang memiliki kompetensi profesional dalam bidang tersebut, yang setiap tahun dilakukan oleh Lembaga Pengabdian pada Masyarakat (LPM) Universitas Negeri Manado. Cara ini dimaksudkan untuk mengubah kondisi yang ada sekarang ini kepada kondisi yang diharapkan yaitu kurang luasnya wawasan guru karena kurangnya pengetahuan dan ketrampilan serta motivasi yang 
diperlukan dalam berinovasi menggunakan model-model pembelajaran bahasa. Kondisi mi akan dibawa kepada kondisi yang diharapkan, yaitu adanya perluasan dalam wawasan dan peningkatan dalam pengetahuan dan keterampilan serta motivasi yang memung- kinkan mereka dapat menyelenggarakan proses pembelajaran dengan menggunakan dan menerapkan model model pembelajaran bahasa pada berbagai bidang ilmu yang guru tekuni.

Secara umum, kerangka pemecahan masalah disajikan dalam Tabel 1.

Tabel 1. Kerangka Pemecahan Masalah

\begin{tabular}{|c|c|c|}
\hline Kondisi yang ada & Pelatihan singkat & Kondisi yang diharapkan \\
\hline $\begin{array}{l}\text { Kurang luasnya wawasan } \\
\text { guru tentang pendidikan } \\
\text { pengetahuan dan keteram- } \\
\text { pilan yang diperlukan dalam } \\
\text { bermotivasi menggunakan } \\
\text { model-model pembelajaran. }\end{array}$ & $\begin{array}{l}\text { Faktor-faktor pendukung: } \\
\text { * Tersedianya bantuan dana } \\
\text { melalui program penerap- } \\
\text { an IPTEKS pada Lembaga } \\
\text { Pengabdian Masyarakat } \\
\text { Unima; dan } \\
\text { * Adanya sambutan yang } \\
\text { baik dari pihak pemerintah } \\
\text { setempat. } \\
\text { Faktor-faktor penghambat: } \\
\text { Keterbatasan waktu, baik } \\
\text { pada pihak pelaksana } \\
\text { (Dosen Unima), maupun } \\
\text { pihak peserta (guru); } \\
\text { Belum maksimalnya fasi- } \\
\text { litas yang menunjang pe- } \\
\text { laksanaan kegiatan pelatih- } \\
\text { an ini; } \\
\text { Sulit mendapat fasilitas } \\
\text { dalam jumlah yang cukup } \\
\text { banyak secara gratis untuk } \\
\text { digunakan dalam pelatihan } \\
\text { ini; dan } \\
\text { Agak sulit mendapatkan } \\
\text { tempat/ruangan untuk pe- } \\
\text { laksanaan kegiatan ini. }\end{array}$ & $\begin{array}{l}\text { Adanya perluasan pengeta- } \\
\text { huan, keterampilan, motivasi, } \\
\text { kreativitas serta inovatif yang } \\
\text { memungkinkan para guru } \\
\text { dapat menggunakan/ mene- } \\
\text { rapkan model pembelajaran } \\
\text { inquiri secara optimal, efektif } \\
\text { dan efisien. }\end{array}$ \\
\hline
\end{tabular}

Dengan memanfaatkan faktor-faktor penunjang yang ada, serta mengendalikan faktor-faktor penghambat seperti digambarkan di atas, maka diharapkan kegiatan pelatihan ini dapat memberikan hasil yang optimal Kegiatan pengabdian pada masyarakat ini dilaksanakan berdasarkan: Surat Perjanjian Pelaksanaan Pengabdian kepada Masyarakat dana PNBP di LPM Universitas Negeri Manado Tahun 2016.
Dalam pelaksanaan kegiatan ini, diikuti oleh beberapa guru - guru sekolah dasar Kecamatan Sario Manado Tengah. Metode yang digunakan dalam pelatihan ini adalah dengan presentasi, tanya jawab, demonstrasi, pemberian tugas, dan studi kasus. Pada akhir pelaksanaan pelatihan, diberikan kesempatan kepada setiap peserta untuk memberikan tanggapan terhadap pelaksanaan pelatihan ini serta 
memberikan pemahaman tentang bahan pelatihan yang sudah diikuti lewat tanggapan-tanggapan tersebut dapat dijadikan bahan penilaian untuk melihat ungkat keberhasilan dari pelatihan yang sudah diberikan.

Untuk menilai sejauh mana keberhasilan pelaksanaan kegiatan program penerapan pelatihan ini telah dilakukan evaluasi terhadap peserta. Evaluasi dilakukan selama kegiatan dengan memberikan beberapa tugas yang harus dikerjakan oleh semua peserta dan melakukan tanya jawab. Semua hasil tugas dan hasil tanya jawab dijadikan sebagai bahan penilaian keberhasilan pelatihan yang telah dilaksanakan. Seluruh hasilnya dirangkum sebagai berikut:

1. Adanya respon positif dari guru-guru bahasa yang mengikuti kegiatan pelatihan tersebut; dan

2. Semua peserta telah menunjukkan kesungguhan dalam mengikuti pelatihan ini mulai dari awal kegiatan sampai pada akhir kegiatan.

\section{KESIMPULAN DAN SARAN}

\author{
Pelaksanaan kegiatan pengabdian \\ pada masyarakat di Kecamatan Sario
}

Manado Tengah dirasakan oleh pelaksana maupun peserta sangat memuaskan. Dengan indikator kehadiran peserta dan antusias peserta pelatihan cukup baik. Hasil dari pelatihan cukup baik. Suasana belajar dan tutorial cukup bagus. Hampir semua peserta mengikuti dari awal sampai akhir. Para pejabat terkait sangat mendukung pelaksanaan pengabdian masyarakat yang dilaksanakan oleh pelaksana.

\section{KEPUSTAKAAN}

Moh. Uzer Usman \& Lilis Setiawati., 2001 Upaya Optimalisasi Kegiatan Belajar Mengajar. Remaja Rosdakarya. Bndung.

Hamzah B Uno. 2007. Model Pembelajaran : Menetapkan Proses Belajar Mengajar yang kreatif dan efektif. Jakarta: PT Bumi Aksara

Usman, M.U. 2002. Menjadi Guru Profesional. Bandung: Remaja Rosda Karya. Pasaribu L. dan Simanjuntak B, 1983. Proses Belajar Mengajar. Tarsito Bandung Aswan Zain. 2002. Strategi Belajar Mengajar. Rineka Cipta. Jakarta.

L Hamzah B. 2012. Perencanaan Pembelajaran. Bumi Aksara. Jakarta. 
Jurnal ABDIMAS, Vol. 9, No. 2, Desember 2016

ISSN: 1979-0953 